\title{
Pragmatic Analysis of Textbooks on the Basis of Speech Acts
}

\author{
a Samina Ali Asghar, ${ }^{\mathrm{b}}$ Tayyabba Yasmin, ${ }^{\mathrm{c}}$ Aniqa Rashid \\ ${ }^{a}$ Lecturer, University of Education, Lahore, Pakistan \\ Email: Samina.asghar@ue.edu.pk \\ ${ }^{\mathrm{b}}$ Associate Professor, University of Education, Lahore, Pakistan \\ Email: tayyaba.yasmin@ue.edu.pk \\ ${ }^{c}$ Assistant Professor, National University of Modern Languages Faisalabad Campus, Pakistan \\ Email: ansrashid@numl.edu.pk
}

\begin{tabular}{ll}
\hline ARTICLE DETAILS & ABSTRACT \\
\hline History: & This study investigates five speech acts of declaratives ,expressives, \\
Accepted 25 May 2021 & representatives, directives and commisives in three English textbooks at \\
Available Online June 2021 & $\begin{array}{l}\text { the level of III, IV and V published by Punjab Text Book Board Lahore in } \\
\text { order to show whether they are appropriate on pragmatic level for EFL }\end{array}$ \\
Keywords: & learners or not. The results of the study reveal that the distribution of all \\
Pragmatic Analysis, Textbooks, & the speech acts is not equal both within each textbook and among \\
Speech Acts, EFL Teachers & textbooks at all three levels. Among five speech acts, representative \\
JEL Classification: & speech act occurs the most frequently in all textbooks while \\
I21 & commissiveis the least used speech act. None of the books uses any \\
& speech act of declarative. This study implies that EFL teachers and \\
DOI: 10.47067/real.v4i2.164 & materials designers should consider pragmatic aspects to improve the \\
& quality of both learning and instruction.
\end{tabular}

(C) 2021 The authors. Published by SPCRD Global Publishing. This is an open access article under the Creative Commons AttributionNonCommercial 4.0

Corresponding author's email address: Samina.asghar@ue.edu.pk

\section{Introduction}

Pragmatic competence in foreign language contexts is described as the knowledge of speech acts and the skills to use the language appropriate to the situation (Kasper \&Roever, 2005).It is a fact that pragmatics performs a very significant part in producing and comprehending a language. It has an essential role in the process of communication. Therefore, language speakers should have ample pragmatics knowledge to produce the desired utterance according to the social settings.

Researches in the field of foreign language have showed that generally learners use the norms of their own culture while using the foreign language. It causes pragmatic failure, i.e. the failure in inferring the meaning of speaker. It often happens in the communication that takes place in crosscultural or intercultural contexts, and it performs a pivotal role in the acquisition of foreign language (Thomas, 1983).

Kasper and Schmidt (1996) pointed out that learners are better able to develop their pragmatic competence if they receive richer input of social and cultural features. Target language country may 
provide learners with such enriched environment for their pragmatic development than that they receive in restricted classroom setting. Takahashi and Beebe (1987) supported this idea in their work which showed that ESL learners' refusals were more near to native speakers than responses provided by EFL learners.

The results of previous researches indicated that communicative competence of EFL learners or ESL learners is based upon their knowledge of target culture. Bentahila and Davis (1989) distinguished between knowledge of language and behavioral knowledge related to culture of target language. Wolfson (1989) asserted that concept of cultural variation goes deeper even from level of speech acts. Function of speech acts varies from culture to culture. Every speech community determines norms and values of interaction by itself to be followed by its members (Coulmas,1981).

Pragmatic competence is a major issue in developing pedagogy .Especially in foreign contexts, students acquire the conversational norms of target language by getting exposure to the authentic material that represents actual ways of speaking. Students are not provided sufficient pragmatic knowledge in English textbooks to develop their ability to use language in different social contexts. That's why they are not ready to be having appropriately in a given context (Grant \& Starks, 2001). Textbook writers and instructors are required to make changes in their approaches to L2 teaching, since restrictions imposed by textbooks and the classroom on appropriate pragmatic input obstruct the development of learners' proficiency in communication (Koike, 1989).

Despite the limitations of the textbook, it is regarded as the principal element of the classroom (Altbach, 1991). Correspondence between the textbooks and language use, curriculum and lesson planning is needed to be developed for a more improvement in ELT textbooks. After the earlier studies on the analysis of pragmatics knowledge in textbooks, the present study was conducted to examine what types of speech acts were present in EFL textbooks.

This study aimed at evaluating English Text Books of grade III, IV and V published by Punjab Text Book Board, Lahore in terms of speech acts. The researcher drew on the taxonomy of illocutionary acts proposed by Searle (1969). The following research questions were aimed to answer in this study:

1. What are the types of speech acts in English text books?

2. What are the similarities and differences among English Textbooks in the distribution of speech acts?

3. To what extent are conversations in English textbooks pragmatically appropriate in terms of the five types of speech acts?

\section{Methodology}

\subsection{Materials}

This study aims to evaluate three English textbooks of grade III, IV and V published by Punjab

Text Book Board, Lahore.

\subsection{Instrumentation}

The researcher applied model of speech acts proposed by Searle(1969) in order to investigate five types of speech acts. Searle (1976) presented the taxonomy of the types of illocutionary acts. This taxonomy involves five functions which are performed by speech acts: (1) Declarative: e.g. performing declaration, (2) Representatives: e.g. asserting, describing, (3) Expressive: e.g. greeting, apologizing, (4) Directive: e.g. commanding, suggesting, (5) Commissive: e.g. promising, refusing, and threatening. 
Following Searle (1979), Yule (1996), presented the summary of general functions of five speech acts:

Table 1: Functions of speech acts (Yule, 1996)

\begin{tabular}{|l|l|l|}
\hline Speech act type & Direction of fit & $\begin{array}{l}\text { S = speaker } \\
\text { X = situation }\end{array}$ \\
\hline $\begin{array}{l}\text { Representatives } \\
\text { Directives } \\
\text { Expressives } \\
\text { Commissives } \\
\text { Declaratives }\end{array}$ & $\begin{array}{l}\text { make words fit the world } \\
\text { make the world fit words } \\
\text { make words fit the world } \\
\text { make the world fit words } \\
\text { words change the world }\end{array}$ & $\begin{array}{l}\text { S believes X } \\
\text { S wants X } \\
\text { S feels X } \\
\text { S intends X } \\
\text { S causes X }\end{array}$ \\
\hline
\end{tabular}

\subsection{Data collection procedure}

Role of dialogues in provision the situations for speakers in using speech acts in their speech cannot be ignored. Thus, in order to measure the weight of speech acts, the conversation parts in the textbooks were analyzed. The researcher examined all the conversations available in the textbooks. The conversations varied both in length and in number.

\subsection{Data analysis procedure}

The data were analyzed by applying classification of speech acts presented by Searle (1969).It recognizes five types of speech acts, i.e. declarative, representative, expressive, directive commissive. Frequency of the speech acts were calculated in order to find out their distribution in conversation parts of textbooks.

\section{Results and Discussion}

The following table illustrates the frequency of five speech acts in each three levels of textbooks.

Table 2.Frequency of speech acts

\begin{tabular}{|c|c|c|c|c|c|c|c|c|c|c|c|}
\hline \multirow{3}{*}{ English III } & \multirow{2}{*}{\multicolumn{2}{|c|}{$\begin{array}{l}\text { Representatives } \\
\mathrm{N} \quad \%\end{array}$}} & \multirow{2}{*}{\multicolumn{2}{|c|}{$\begin{array}{l}\text { Declaratives } \\
\mathrm{N} \quad \%\end{array}$}} & \multicolumn{2}{|c|}{ Expressives } & \multicolumn{2}{|c|}{ Directives } & \multicolumn{2}{|c|}{ Commissives } & \multirow{3}{*}{$\begin{array}{l}\text { total } \\
103\end{array}$} \\
\hline & & & & & $\mathrm{N}$ & $\%$ & & & $\mathrm{~N}$ & $\%$ & \\
\hline & 41 & 39.80 & $\mathrm{O}$ & $\mathrm{O}$ & 18 & 17.47 & 41 & $\begin{array}{l}39.8 \\
\text { o }\end{array}$ & $\mathrm{O} 3$ & 2.90 & \\
\hline English IV & 14 & 29 & $\mathrm{O}$ & $\mathrm{O}$ & 13 & 26.5 & 20 & 41 & $\mathrm{O} 2$ & 5 & 49 \\
\hline English V & 56 & 42.74 & $\mathrm{O}$ & $\mathrm{O}$ & 34 & 26 & 37 & $\begin{array}{l}28.2 \\
4\end{array}$ & $\mathrm{O} 4$ & 3.05 & 131 \\
\hline
\end{tabular}

Table 2 shows the frequency of speech acts used in English text Books of Punjab Text Book Board, Lahore. Variation was observed in the number of speech acts used in all of the three books. In English III, the most preferred speech acts were representatives and directives, i.e. 39.80\%. The next preferred speech act was expressive speech act whereas in English IV, the most frequent speech act was directive. Expressive and representative speech acts were found at the same level of frequency. Analysis of speech acts in English V indicated that representative speech acts are at the highest level of frequency 
(42.74\%) whereas the next preferred speech acts were expressive and directives, i.e. $34 \%$, 37\% respectively. None of the English books used the speech act of declarative.

There is inconsistency in the use of speech acts in all three books. Frequency of speech acts does not increase with the increase level of book. English III uses 103 speech acts total. This size decreases in English IV whereas in English V, frequency of speech acts increases especially in case of representative speech acts. Analysis reveals that these books need to add pragmatic information regarding speech act according to their preference at each level.

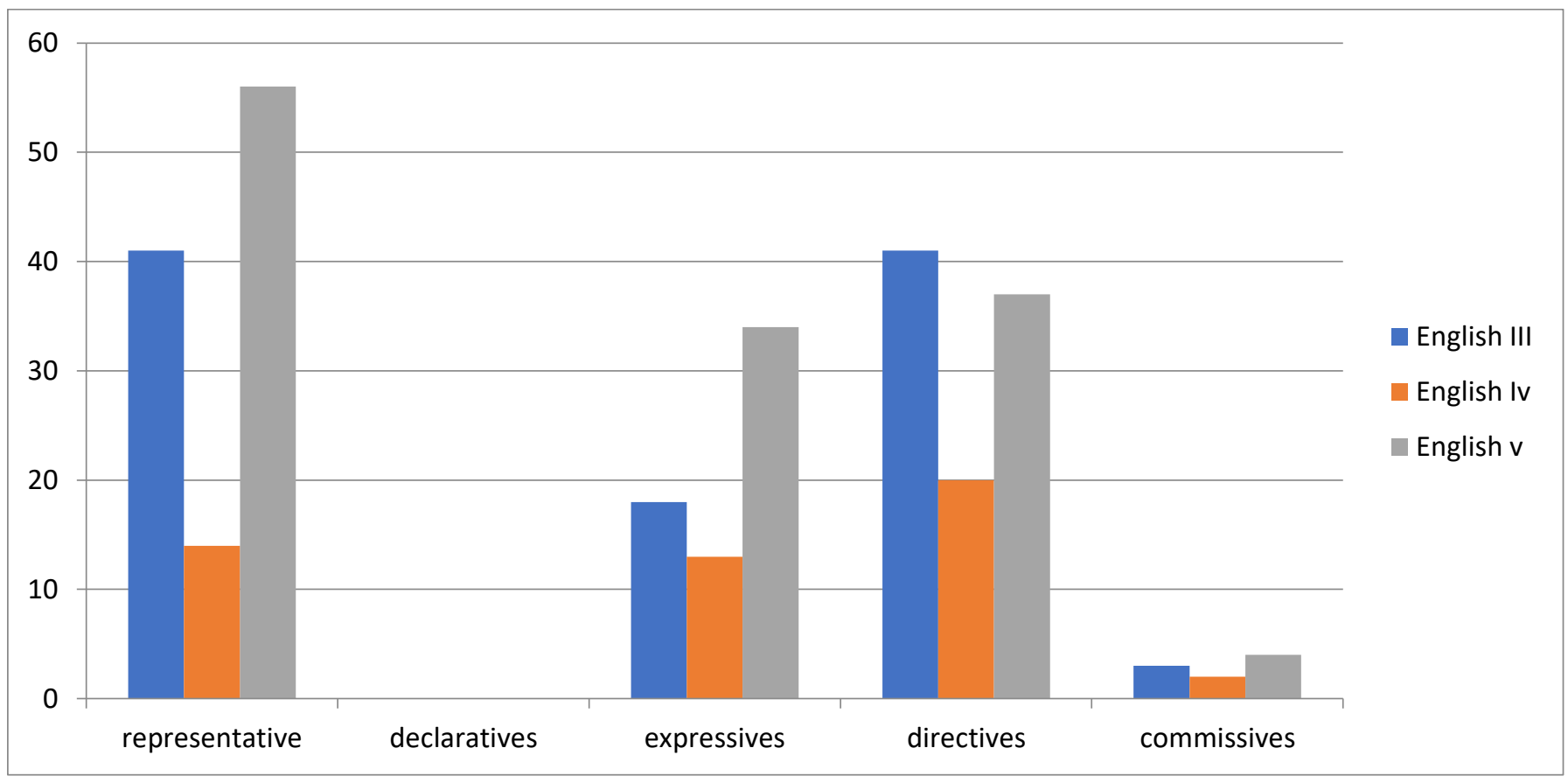

Figure 1: Frequency of speech acts in three books.

\section{Conclusion and Implications}

Based on the findings of the study, the following conclusions were drawn:

This study revealed that three textbooks such as English III, English IV and English V are not pragmatically competent and fruitful for learners who are in the need of communicative competence to gain command on target language. Moreover, the researcher analyzed all conversations in the books and indicated that the PTB books do not have sufficient data regarding communicative competence. Due to unequal distribution of speech acts, the learners may get exposed to some speech acts but are unable to produce others. Besides this, speech acts' exposure to learners in these books does not increase with the rise of the level of textbooks.

The implications of this study for the teachers, material developers and institutions are to take into account of pragmatic aspects in textbooks and provide supplementary material to strengthen the pragmatic dimensions in instruction. Focusing on functions of language and speech acts could be best supplement in this regard.

\section{References}


Altbach, P.G. (1991). The unchanging variable: Textbooks in comparative perspective. In P.G. Altbach, G.P. Kelly, H.G. Petrie and L. Weis (Eds.), Textbooks in American society: Politics, policy and pedagogy (pp. 237-254). Albany, NY: State University of New York Press.Cohen, A. D. \&Olshtain, E. (1993). The production of speech acts by EFL learners'. TESOL Quarterly,27(1), 33-56.

Bentahila, A., \& Davies, E. (1989). Culture and language use: A problem for foreign language teaching. International Review of Applied Linguistics in Language Teaching, 27, 99-112.

Coulmas, F. (1981). "Poison to your soul": Thanks and apologies contrastively viewed. In F. Coulmas (Ed.), Conversational routine: Explorations in standardized communication and prepatterned speech (pp. 69-91). The Hague: Mouton.

Grant, L., \& Starks, D. (2001). Screening appropriate teaching materials: Closing from textbooks and television soap operas. International Review of Applied Linguistics in Language Teaching, 39, 39-50.

Kasper, G. \&Roever, C. (2005). Pragmatics in second language learning. In Eli Hinkel (ed.). Handbook of Research in Second Language Teaching and Learning, pp. 317-334. Mahwah: Lawrence Erlbaum Associations.

Koike, D. A. (1989). Pragmatic competence and adult L2 acquisition: Speech acts in interlanguage. The Modern Language Journal, 73, 279-289.

.Searle, J. (1969). Speech acts: An essay in the philosophy of language. Cambridge: Cambridge UniversityPress.

Takahashi, T., \& Beebe, L. M. (1987). The development of pragmatic competence by Japanese learners of English. Japan Association for Language Teaching Journal, 8, 131-155.

Thomas, J. (1983). Cross-cultural pragmatic failure. Applied Linguistics, 4, 91-122.

Wolfson, N. (1989a). The social dynamics of native and non-native variation in complimenting behavior. In M. Eisenstein (Ed.), The dynamic interlanguage: Empirical studies in second language variation (pp. 219-236). New York: Plenum Press.

Yule, G. (1996). Pragmatics. New York: Oxford University Press. 